University of South Florida

DIGITAL COMMONS

Digital Commons @ University of

@ UNIVERSITY OF SOUTH FLORIDA

South Florida

Tampa Library Faculty and Staff Publications

Tampa Library

2019

Copyright Educational Services and Information in Academic

Libraries

LeEtta Schmidt

University of South Florida, Imschmidt@usf.edu

Follow this and additional works at: https://digitalcommons.usf.edu/tlib_facpub

Part of the Library and Information Science Commons

Scholar Commons Citation

Schmidt, LeEtta, "Copyright Educational Services and Information in Academic Libraries" (2019). Tampa Library Faculty and Staff Publications. 16.

https://digitalcommons.usf.edu/tlib_facpub/16

This Article is brought to you for free and open access by the Tampa Library at Digital Commons @ University of South Florida. It has been accepted for inclusion in Tampa Library Faculty and Staff Publications by an authorized administrator of Digital Commons @ University of South Florida. For more information, please contact digitalcommons@usf.edu. 
Copyright Educational Services and Information in Academic Libraries LeEtta Schmidt

ORCiD: orcid.org/0000-0002-9567-9065

University of South Florida

This is an Accepted Manuscript of an article published by Taylor \& Francis in the Public Services Quarterly on 14 Nov 2019, available online: https://doi.org/10.1080/15228959.2019.1644267 


\section{Copyright Educational Services and Information in Academic Libraries Abstract}

Library and information science literature tells a story of the recent surge in creation the copyright librarian positions in academic libraries from identification of need to construction of job responsibilities and position requirements. This article seeks to continue the story by identifying what information materials and services the librarians responsible for providing copyright assistance have created at their libraries, and how those services are delivered to their institutions. An examination of 115 library websites is employed to identify topics and foci within copyright services with the goal of establishing commonalities of service among U.S. research one libraries that can be used to inform new service development.

Keywords: copyright, intellectual property, library services 


\section{Copyright Educational Services and Information in Academic Libraries Introduction}

Discussions on if and why copyright education services should be placed in the library, how libraries are hiring to address patron demands for copyright services, who should deliver those services, what they need to know, and how they may be unprepared for the role due to an inadequacy of Library and Information Science (LIS) Masters programs, abound in the literature of academic libraries. Through the literature we know that, based on increasing demand for specialized services, more libraries have been creating and advertising positions that deal specifically with copyright services or provide assistance on copyright as a central part of their job. It is not surprising then, that the amount of LIS literature devoted to copyright issues, as recorded in LIS Abstracts, increased dramatically from 2007-2013 compared to the twenty years previous (Hansen, Cross \& Edwards, 2013). Not only would libraries be investigating the real demand for copyright expertise in order to justify the creation of new positions, the incumbents of those positions would be conducting environmental scans to strategically develop their roles.

Without an established service model to follow, each library would have to start from scratch to determine what information their communities were most interested in and what type of service delivery would work best for their institution. Most studies represented within the literature focus on how services are provided and situated within libraries, but do not give further information on what types of information libraries are providing within those services. These services are often developed in response to either patron demand or to the observed opportunity to educate patrons on a complex topic (Bay, 2001; Charbonneau \& Priehs, 2014). As a user driven service, at least in part, the subject matter of copyright instruction would be 
driven by patron need. Whether a copyright librarian educates herself on a specific section of copyright or intellectual property law could also be tied to user need. Do faculty and students on campus heavily use music in multimedia projects? Is there a frequent instance of open to the public movie screenings on campus? Questions like these can influence the type of information libraries provide to patrons.

This study hypothesizes that copyright services, though still fledgling, have had enough time to naturally develop commonalities that could be used as a map by libraries newly establishing this service. This article will attempt to uncover common topics and subject areas within copyright information services. It will briefly examine the literature regarding the development of the copyright librarian position and related services. It will then expand on the available literature through a survey and examination of publicly available copyright information and services on one hundred and fifteen websites of research one institutions, to determine a more complete picture of the breadth of services that libraries have created to fulfill this demand for copyright service. The results will show which information topics and services are standard across many libraries, creating a foundation upon which to base new service development.

\section{Literature Review}

Studies of LIS masters programs have pointed out that the lack of required courses discussing legal issues in libraries, including issues of copyright and intellectual property, leaves LIS graduates unprepared to meet the ALA core competencies suggested knowledge of the law (Cross \& Edwards, 2011). Although the prevalence of intellectual property topics in LIS courses has risen recently, many graduates still report feeling their instruction was insufficient to meet 
Running Head: COPYRIGHT EDUCATIONAL SERVICES

the demands of their jobs (Schmidt \& English, 2015). A study by John Eye (2013) found that even deans and directors located instruction on intellectual property and other legal issues outside of their LIS degrees, and relied on specialists employed by their library to become involved in copyright issues.

Many studies point out the need for copyright instruction at institutions of higher education, and the usefulness of having it in the library. As Rebecca Albitz (2013) found in her survey of academic copyright officers, the library is considered an accessible and neutral ground. As such, it is perfectly situated to provide copyright information services to faculty and students regardless of department. Libraries' historical association with information literacy further integrates the idea of copyright services into the library. With the many copyright issues affecting libraries increasing due to the development of our digital environment, Donna Ferullo (2004) recommended that librarians have as much at stake in the discussion of institutional policy as any other constituent. The American Library Association's Framework for Information Literacy (2015) emphasized the need for knowledge of copyright and intellectual property constructs as part of an overall information literacy program. This call for copyright services in the library is not one relegated to U.S. libraries. Sam Cheng and Christina Winter (2014) commented on a similar demand for resources and services in Canadian libraries and offered ways of integrating the Association of College and Research Libraries Information Literacy Competency Standards for Higher Education with Canadian copyright law. In Scandinavian libraries there has been a strong and growing focus on copyright issues in scholarly publishing and open access services, though there is little interest in general copyright services (Nilson, 2016). Even so, Inga-Lill Nilsson (2016) reported that most of the activities 
Running Head: COPYRIGHT EDUCATIONAL SERVICES

librarians currently participate in involve some aspect of copyright even though few librarians receive training in copyright issues. This may contribute to the lack of confidence in providing copyright assistance or instruction that many librarians reported. This lack of confidence has been recorded by other researchers in other countries as well. Louise Carson and Kathryn Greenhill (2015) recorded the same observation in their review of literature about UK library services and their comparison of Australian library copyright services, and a study by the author and Michael English (2015) of U.S. librarians received the same input from survey respondents. In her interviews with institutional copyright officers of the Consortium on Institutional Cooperation, Albitz (2013) found that common copyright services included consultations, education, policy making, and advocating for copyright that supports scholarship and research. She stressed, in her findings, that library located copyright officers should not act as copyright police (Albitz, 2013). Similarly the common duties of copyright librarians in Australia included advice on the use of materials, staff development training, production of information literature, as well as the administration of copyright licenses (Carson \& Greenhill, 2015). In the Library Publishing Toolkit, copyright issues arise with respect to the library as a content creator, adding the responsibilities of establishing author agreements, registration processes, and helping to locate not in copyright materials within library collections (Brown, 2013). Creating or guiding policy and procedure, with emphasis on library services that rely especially on exceptions to copyright law, is also a responsibility highlighted in a study by Hansen, Cross and Edwards (2013), who emphasized the importance of practice and policy combined as it was recently reviewed in the litigation involving Georgia State University's e-reserves service. With sundry responsibilities added or removed depending on where a copyright librarian position is located 
within the library, most commonly scholarly communication or electronic resources (Kawooya, Veverka \& Lipinski, 2015), the prevailing duty seems to be one of education. This can take the form of consultations and/or class visits, or be developed into a robust "road show" style program, a menu of workshop topics designed to bring information to established faculty retreats, like the one developed at Utah State University (Duncan, Clement \& Rozum, 2013). Figuring out the kinds of services and outreach that each institution needs by an environmental survey and analysis is one of the most important parts of setting up a copyright office according to Donna Ferullo (2001); after which services, web presence, and helpful tools can be created.

Also in the interviews Albitz (2013) conducted, was the general agreement on the importance of institutional copyright officers having a Juris Doctorate (JD), or some kind of legal degree, for legitimacy, greater ease understanding court decisions, and knowledge of the legal system. It is important to note that this input primarily came from copyright officers who themselves had a JD, half of which were located with general counsel and not in the library. This emphasis on credentialing of copyright officers may be tied to the concern that librarians without legal degrees might give the mistaken impression that their input is legal advice. Kenneth Crews, quoted regarding the launch of Harvard's Copyright First Responders, echoed this concern, cautioning that copyright first responders "understand clearly what questions they should answer and what questions they should NOT answer (Peet, 2014)." Nevertheless, a 2015 analysis of ALA JobList postings showed that none of the 264 jobs that mentioned copyright as a primary or secondary duty required a JD, and only five even listed it as a preferred qualification (Kawooya, Veverka \& Lipinski, 2015). 
There have been very few studies dedicated to what copyright information and services are advertised on library websites. As well as providing some documentation on what types of information are provided, these studies also evaluate the accessibility of the information by either conducting in site searches or by recording how many clicks are required for a website visitor to access the information from the home page with the understanding that more clicks relates to less accessibility. One analysis of libraries in Russia, Israel and the United States looked at online copyright information as a reflection of what the library recognized as important as well as a reflection of the demands on libraries to provide the information (Shachaf \& Rubenstein, 2007). The study found that, of the three countries, Israel and the U.S. hosted copyright information on their web sites. Most U.S. libraries focused, in order of importance, on e-reserves, an FAQ, library policies, e-resources, and document delivery. This information, on average, required at least two clicks to access. In comparison, Israeli libraries situated copyright information only one click into the site, however, offered less variety of information: e-resources and reserves (Shachaf \& Rubenstein, 2007). A follow-up study of the same method by Wang \& Yang (2015) looked at copyright information on the websites of Chinese and Japanese libraries. Library provided copyright information was most prevalent on Japanese library websites and commonly addressed a guide for users, e-resources, an about section with links out, descriptions of library services, and an FAQ. The Chinese library websites studied covered e-resources, a guide for users, and an about section with links out (Wang \& Yang, 2015). Both studies found that the libraries delivering less information, i.e. Israeli and Chinese, focused primarily on avoiding infringement, while the libraries with more information incorporated more educational resources. A similar study, but of a different method, was 
conducted by Tony Horava (2008) of Canadian institutions. Horava's study found that $57.3 \%$ of the libraries surveyed had a copyright information page on their websites, and about half of the pages were two clicks away from the main page. However his information did not include the topics or types of service available on those pages. These articles provide the most similar information to the current study, however, only one, that of Shachaf \& Rubenstein (2007), addresses academic libraries in the U.S at all. The information on U.S. academic libraries collected by this study focused primarily on accessibility, only hinting at the types of copyright information each website offered. After establishing the need for a new library service, the next questions are often 1.) what service or information should be provided and 2.) how will that service be delivered. The existing literature gives partial, but not complete, answers to these questions. To fill in the remaining pieces of the questions, this study will look at the service activities of libraries as advertised on public facing websites.

\section{Method}

The goal of the current study was to ascertain the composition of library copyright services, and the types of information provided via those services, in U.S. academic libraries to identify trends and standard practices that could be used as a guideline for libraries new to creating copyright services and information webpages. The data collected for this study consisted of publicly available information on one hundred and fifteen websites belonging to libraries which were part of an institution that had a Carnegie classification of Doctoral Research 1 as of 2017 (Carnegie Classification of Institutions of Higher Education, 2017). By focusing on research 1 institutions to form the population for the study, the author hoped to facilitate connections to other studies that used similar criteria, as well as produce results that 
would give further information on the peer libraries of the author's own institution. The existence of information on copyright services and companion educational material on library websites was chosen both as an indicator of the library and institutional value placed on these services (Shachaf \& Rubenstein, 2007), as well as evidence of patron demand on the library regarding copyright issues. Beginning in early 2018, each library website was checked for the

- type and topics of copyright information offered,

- the type of services provided by the copyright office or librarian,

- the configuration of the office and title of the librarian,

- the librarian's credentials,

- whether the library had a posted copyright policy, and

- whether the library had posted terms of use information.

This information was often not in any one location on a library's website. The websites were approached as an external user or library patron would approach their library if not familiar with it. Searches were begun on the library's home page. From there, service landing pages, research assistance pages, and guide directories were checked for any link or information mentioning copyright or related services. Staff directories were checked next, for both librarian titles and possible links to content, followed by library administration and policy pages. Materials labeled as library policies, or included on a webpage designated for policies, were checked for references to copyright. Finally, website and/or guide search functions were utilized if available. If any one piece of information could not be found via the intuitive navigation through the site, as described above, or by using the website's internal search abilities, the library would be marked as not having that particular information. Librarian 
Running Head: COPYRIGHT EDUCATIONAL SERVICES

credentials, specifically, whether a librarian possessed a JD, were often found on web pages external to the library, like online scholar profiles. If credentials could not be found, those librarians were excluded from the analysis regarding the prevalence of a JD among copyright librarians. Individual libraries and librarians were not contacted.

To discern whether library size and funding had an effect on the services offered by any one library, National Center for Education Statistics library statistics in regard to both collection size and total expenditures were also collected. The collection size of the libraries averaged $8,779,078$ with a range of $27,092,529$ and a median at approximately $8,400,000$. The reported total expenditures of the libraries averaged $\$ 15,512,175$ with a range $\$ 46,982,159$ and a median at approximately $\$ 14,600,000$ (National Center for Education Statistics, 2017).

\section{Limitations}

There are few limitations to the study, relating primarily to information that was not or could not be easily collected. The presence of information on library websites was taken as an indicator of service and the importance of service provision to the libraries as whole entities. While various characteristics of institutional organization could affect the services provided by the library, for example, the presence of general counsel dedicated to intellectual property issues and actively providing instruction, the make-up and organization of Research 1 institutions was not specifically analyzed. These relationships were not often visible or easily discoverable, making their inclusion in the study untenable. Future study into how relationships between libraries and institutional general counsel inform library copyright services may require direct feedback from librarians in charge of copyright services. 
Running Head: COPYRIGHT EDUCATIONAL SERVICES

Likewise, the organizational structure of the libraries was not collected due to little or no publicly available information, so the influence of available web developer services and required managerial approval for updates to web pages could not be considered in the current data set. Information provided to library patrons outside of the library website was not sought out or evaluated, nor were any assumptions that copyright information was provided via information literacy instruction or similar services if not explicitly mentioned on the web pages. Though the study gathers information about the individual librarians providing copyright services, it is the library as an entity that is examined in this study. By providing certain information and services via publicly accessible library websites, libraries can indicate which information they want to be most accessible to their community. Similar to Shachaf \& Rubenstein's (2007) study, this study looks at accessibility as an indicator of value. However, the current study did not include any click analysis that would make it more directly comparable to previous studies discussed in the review in the literature. The decision not to conduct a click analysis was made based on the variety of the information sought and the assumption that policy information, librarian contacts, and services may all be located on different areas of the web site.

\section{Results}

The first piece of information sought out from library web pages dedicated to issues of copyright and intellectual property was an identifiable staff member or librarian who could help with additional questions. These contacts were either identified as copyright librarians, librarians or staff with copyright as one duty among other subject specialties, or contact forms with no identifiable individual. Seventy one (62\%) of the 115 institutions had an identifiable 
individual with contact information available on the library web pages. Overall, thirty one (27\%) libraries attributed copyright services to a group, while forty six (40\%) relied on a single individual. Some of the libraries who made reference to a team or group of people providing copyright assistance gave an email or contact form for the group as a whole, without identifying members of the group. A final thirty one (27\%) libraries provided some kind of copyright information without listing any method of contact for further assistance. Of the seventy one libraries that had an identifiable individual as the contact for copyright services twenty had a JD while forty did not. No information could be found on eleven of the librarians. All the librarians with JDs were either Scholarly Communications Librarians or Copyright Librarians. Only 30\% of the Scholarly Communications Librarians had a JD compared to $61 \%$ of Copyright Librarians. Information on whether the copyright librarian was also the copyright officer for their institution was not prevalent enough on library web pages or librarian information pages to be reliably collected.

Only seven of the library websites examined did not offer any type of copyright information or services. Of the remaining $108(94 \%)$, the majority of information and services were associated with the scholarly communications division/department of the libraries (figure 1). Six of the libraries looked at did not directly provide copyright information or services. However they linked to and incorporated online materials from copyright offices independent from the library in way that allowed for seamless navigation between the library site and that of the copyright office. Other departments providing copyright information and services in order of prevalence were outreach, copyright offices, access services, technical services and one university press. 


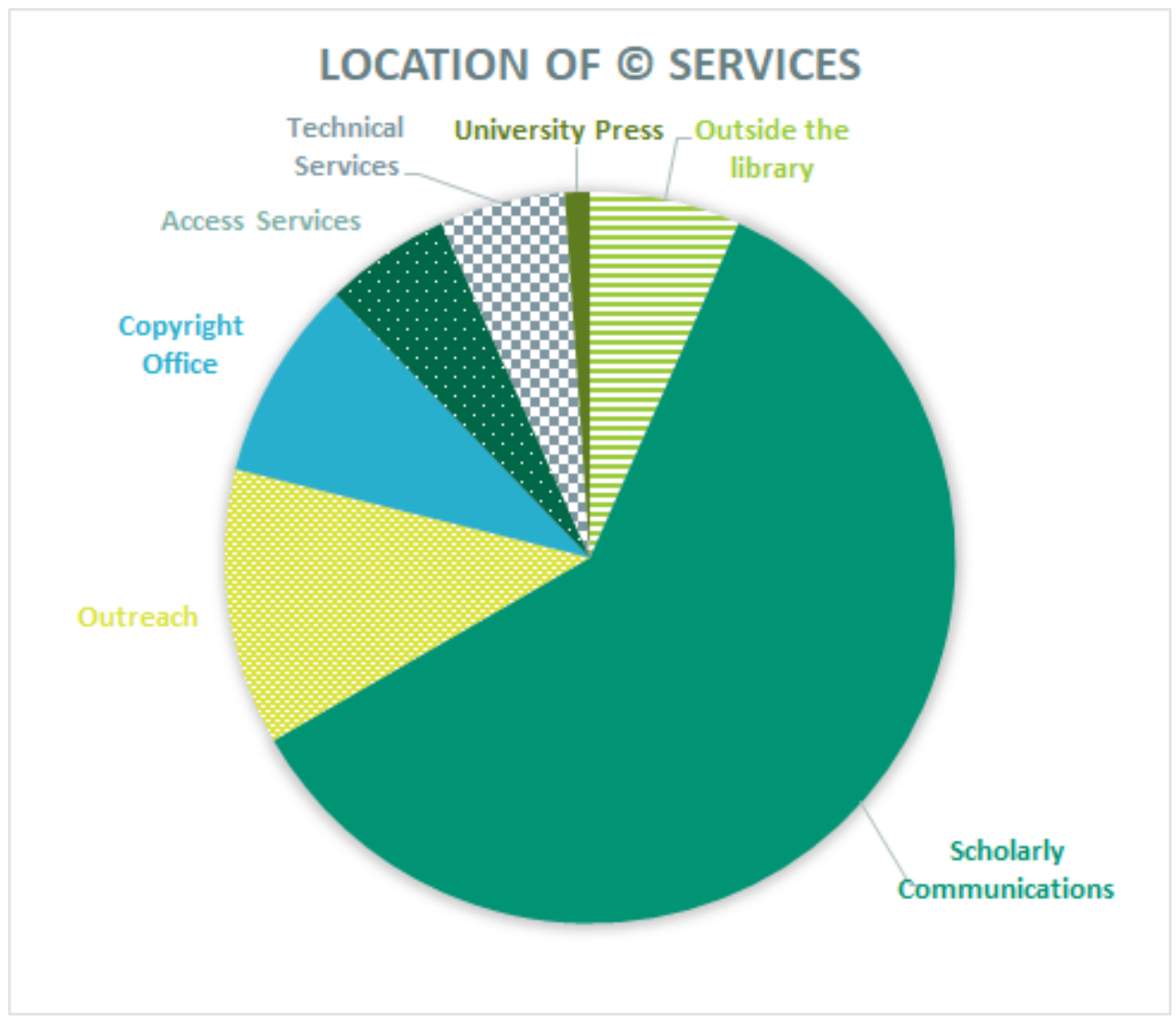

Figure 1: Location of Copyright Services in the Library

Whether the libraries created content for their copyright information services or outsourced by utilizing links to other institutions and organizations was also examined. Web pages were identified as primarily text based, primarily link based, or an equal combination of both. Sixty three library web sites were primarily text based, twenty eight were a balanced mix of text and link, while sixteen were primarily links out to content elsewhere online. To ascertain whether the type of content was dependent on whether an individual was assigned to provide copyright services, the relation of content type to identifiable librarian was examined. The distribution of content type did not vary appreciably dependent on if the libraries had an identifiable contact versus libraries that did not. Each content type was fifty seven to sixty four percent likely to be attributed to an individual as to a group or no identifiable person. Library 
staffing overall seemed to have more correlation to what type of content was provided. The statistics for faculty, professional staff, expenditures, and collection sizes for each institution were arranged by the type of content provided in the copyright services web pages. Those libraries with the most librarians tended to have both text and links; libraries with slightly less librarians but with the most professional staff had the most text centric pages.

Considering the concern expressed in the literature that librarians be clear that the information they provide is not legal advice, website pages were also checked for a disclaimer notifying the reader of this. Forty two library copyright pages had such a disclaimer, sixty six did not. The tendency to have a disclaimer was also checked against the type of content provided. Text based pages were equally likely to have a disclaimer as to not have one; pages with both links and text were slightly less likely to have disclaimers, and pages with mostly links were least likely to have a disclaimer.

Of special interest was the subject matter covered by library copyright pages, as this would indicate the demand for information experienced at the institutions, or the topics selected by librarians as the most important for their patrons. Most of the libraries had information on, in order of prominence: copyright basics (85\%), fair use (85\%), use of copyrighted material in class (68\%), author rights (63\%), and the public domain (59\%). Libraries were equally as likely to have or not have information on requesting permissions (51\%), the T.E.A.C.H. Act (47\%), and Open Access (42\%). They were least likely to have information on plagiarism (20\%), copyright issues specific to images (16\%), film/streaming media copyright (15\%), copyright issues specific to music (14\%), international copyright (8\%), e-resources licenses (7\%), and 3D scanning and printing (2\%) (figure 2). 
Running Head: COPYRIGHT EDUCATIONAL SERVICES

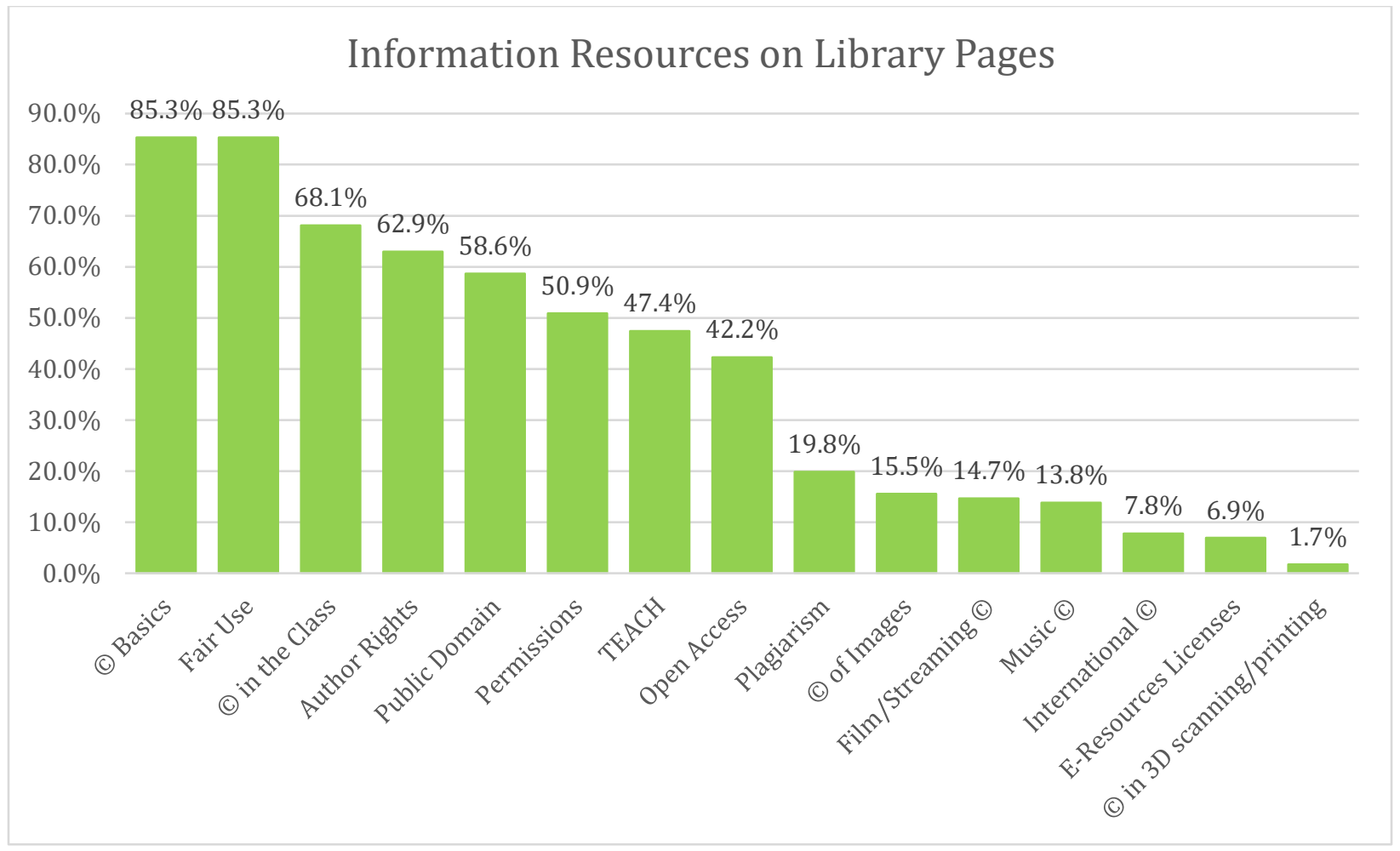

Figure 2: Information topics on library web pages

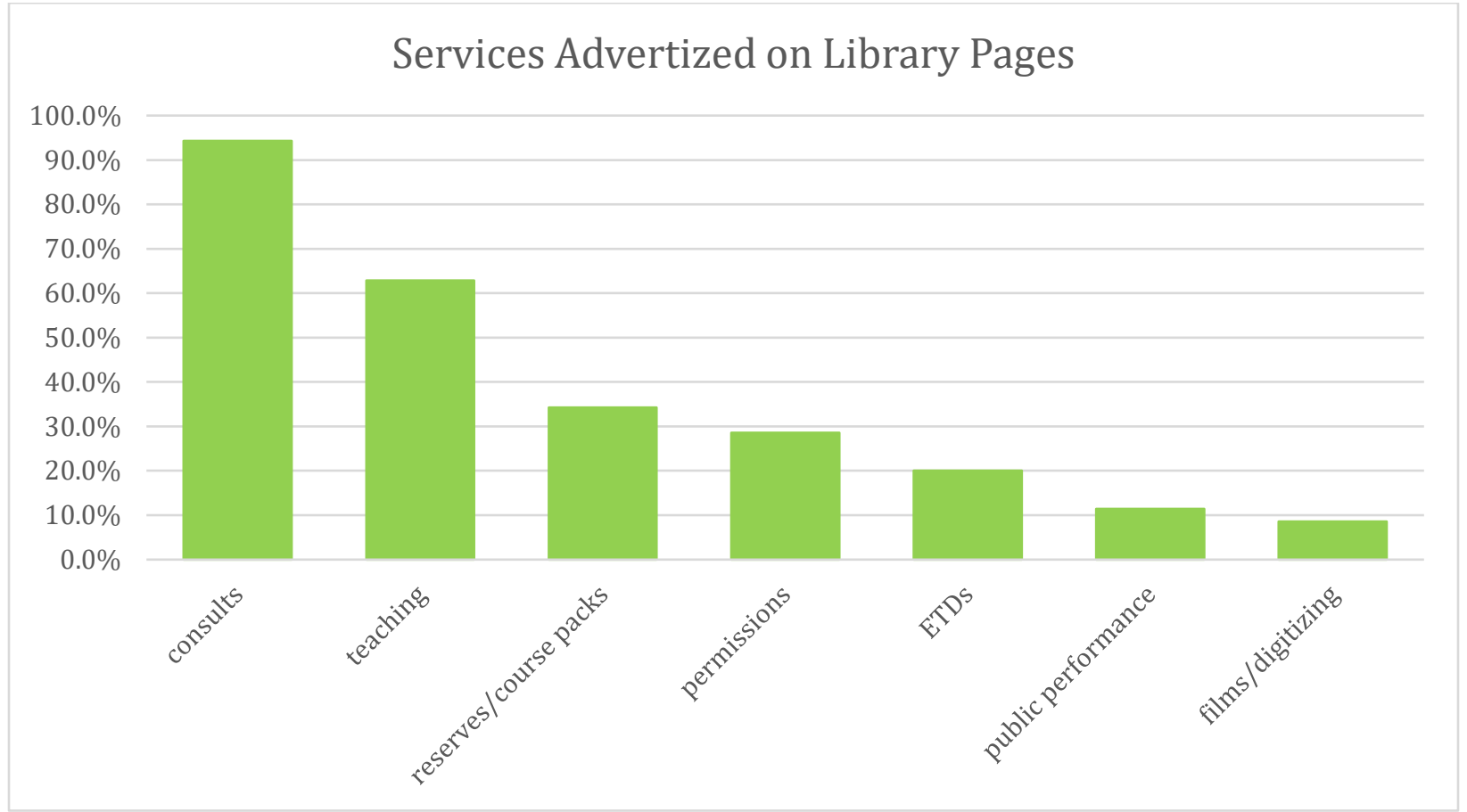

Figure 3: Services advertised on library web pages 
The library web pages were also checked for the types of services offered to their institutional communities. Eighty one did not specifically list any services while thirty five libraries did. Of all the services listed, consultations were the most common at $94 \%$ of the 35 libraries. Following this were instruction sessions (63\%), help with reserves and electronic course packs (34\%), help obtaining permissions ( $29 \%$ ), help with electronic theses and dissertations (20\%), help obtaining public performance rights (11\%), help with obtaining public performance rights, and, finally, help with streaming and/or digitizing films (9\%) (figure 3). Other services offered by individual libraries included help with copyright registration, publisher contracts and author rights, as well as fair use analyses.

Additionally, copyright policies and terms of use pages were located on the library websites, most of which were separate from copyright information and services pages. What constituted a library policy varied among the libraries. While some had linked documents in a specific format, written with explicit mention that the document was a policy, other libraries had self-titled policy pages that included links to informational sources of many kinds. All material that the libraries identified as a policy, by inclusion on a web page or portion of a webpage addressing library policies, was evaluated. Fifty (43\%) of the 115 libraries did not have a discoverable copyright policy. Of the remaining sixty five (57\%) libraries, fifteen referred primarily to copyright issues in electronic reserves, and fifteen dealt only with copyright and user access to electronic resources. Other copyright policies or statements, often linked within library administration pages, referred to the use of digital collections, linked to the copyright services pages, or linked to university policy pages. Few libraries consolidated all copyright issues under one policy. Terms of use pages were also looked for as another avenue through 
which libraries may communicate copyright instruction or information. Terms of use pages also may have information on use of electronic resources, patron privacy, and use of digital collections. Twenty two (19\%) of the 115 libraries looked at had no terms of use page or any component of such a page as listed above. Twenty two (19\%) libraries pointed out to the institutional or state terms of use and/or privacy pages. Sixty one (53\%) libraries specifically had a privacy or confidentiality statement. Only ten (9\%) had complete terms of use that included privacy, copyright and use of resources.

\section{Observations}

The data provided by the study confirms information reported by studies of smaller populations, like the Albitz (2013) study and the review of ALA JobList postings (Kawooya, Veverka \& Lipinski, 2015), that education, often in the form of consultations and in class visits, was the most common service offered in connection with copyright information pages. Information gleaned from the websites hints at some of the goals of these educational services. Specifically, information regarding use of copyright materials in class and about the T.E.A.C.H. Act indicates that copyright services were directed at institutional faculty at least as much as at students and other users. Most often copyright services were linked to scholarly communications. This is in concert with the 2015 study of ALA JobList postings that found many jobs advertised with copyright responsibilities were connected with scholarly communications (Kawooya, Veverka \& Lipinski, 2015). This link to scholarly communications services may explain why author rights were also one of the most popularly addressed subjects in copyright information pages. 
Running Head: COPYRIGHT EDUCATIONAL SERVICES

Based on the information gathered by the study, there appears to be some correlation between staffing and the type of content offered on library copyright information and service pages. The less people available at a library, the more likelihood that copyright information pages will link out to external resources instead of contain text information. Yet, $93 \%$ of Research 1 libraries have mention of copyright information or services on their websites, and $86 \%$ have information covering copyright basics. Regardless of available staffing or the existence of a librarian whose primary or secondary responsibilities include copyright, providing copyright education appears to be a clear priority. The topics covered by copyright information pages differed or have evolved since the 2007 study by Shachaf and Rubinstein. Drawing a connection between what this study calls copyright basics and what Shachaf and Rubenstein's (2007) study called FAQ/instructions/copyright resources/tutorials, the $86 \%$ of research one institutions in 2018 to provide this type of information is a great change from less than $20 \%$ of institutions providing the same information covered in the previous sample of ARL libraries. This confirms the hypothesis gleaned from the literature that copyright services in libraries have been growing both in breadth and in commonality. In addition to information on copyright basics, over half of the libraries examined provided information on fair use, use of copyrighted material in classes, author rights, the public domain, and requesting permissions. Slightly less popular was information on the T.E.A.C.H. Act and open access. The popularity of these specific topics within copyright information pages points to areas of common need on academic campuses and could be used as a guide for libraries newly creating information pages and copyright services. Web pages covering information on fair use, the public domain, and requesting permissions may indicate the demands of library patrons seeking to use copyrighted 
material in new and different ways. While information provided on classroom use and the T.E.A.C.H. Act indicate the level of assistance given to instructors on using copyrighted information in both their in-person and online classes. A third user group, that of authors, possibly including both faculty and students, is represented by pages devoted to author rights, and may illustrate both the presence or overlap of scholarly communications foci with that of copyright services, as well as the interests of institutional authors. Institutions interested in updating or newly creating copyright services in their library would benefit from investigating whether all three user groups are prevalent on their institutional campuses and customizing their copyright services to address each group.

Of equal interest to what library websites included about copyright is what they lacked. That sixty six library sites did not, compared to 42 libraries that did, have a disclaimer making clear that the information provided was educational instead of legal belies the amount this subject gets attention in the literature. It is also interesting that only $13 \%$ of the libraries' web sites examined had policies that addressed copyright issues related to reserves given the 2013 discussion on the need for such policies and documented procedures in light of recent copyright litigation (Hansen, Cross, \& Edwards, 2013). These may represent areas where established services could expand and improve, or might be issues covered within copyright services at libraries, but not represented on library web sites. Librarians in charge of delivering copyright services may deliver a type of disclaimer in their consults and educational sessions, making clear that the information they are providing is not to be considered legal advice. Similarly, institutions may be focusing on perfecting and correcting internal reserves processes to address issues raised by recent copyright litigation, but not posting this information where 
the public has access to it online. Non-public policy and procedure are two areas that the current study failed to include by not soliciting information on library or organizational makeup, or on what topics may be covered in copyright services delivered offline.

Regarding whether librarians tasked with providing copyright informational services require a JD, the lack of this requirement in the ALA JobList study (Kawooya, Veverka \& Lipinski, 2015), and the lack of prominence of librarians with JDs in the analysis of library copyright web pages, where only $29 \%$ of the individually identifiable librarians responsible for copyright services had one, seems to indicate that, at this time, a JD is not a usual job requirement. This information disagrees with the input Albitz (2013) received in her study of academic copyright officers who generally agreed on the importance of a JD in their positions. However, the percentage of identifiable librarians providing copyright services that held a JD shifted for positions specifically titled as copyright librarians with $61 \%$ having a JD. Whether the JD was required at the time of their hire, or the copyright librarian was also the designated copyright officer at the institution, was not reliably found during the evaluation of library and librarian information pages, and so was not included. It is possible that the percentage of copyright librarians with a JD reflects the requirements of a copyright officer position in those librarians performing this dual role.

\section{Conclusion}

If the sample of research one libraries in this study is used as an example in conjunction with the study done previously by Shachaf and Rubinstein (2007), it is clear that providing copyright information services in the library has become part of the standard operations of academic libraries in the U.S. The librarians in charge of these services are often either 
scholarly communications or copyright librarians with a large portion of their job assignment directed at copyright education. This education is aimed equally at all populations of their institutions and addresses topics of concern to faculty and student alike. These areas of concern seem to naturally fall into three areas: basics of copyright and reuse, information regarding the use of copyrighted content in classes, and information on copyright issues for authors. With such a ubiquitous focus on information for using copyright material in class, and the emphasis of The American Library Association's Framework for Information Literacy (2015) for including copyright and intellectual property constructs in information literacy instruction, creating services that reach teaching faculty groups seem to be an area of emphasis. Further investigation into the delivery of copyright services and instruction to faculty groups would be needed to explore the obstacles encountered and various methods that libraries have employed to reach this user group. The roadshow style program, developed by Duncan, Clement, and Rozum (2013), where copyright specialists visit departments with a menu of workshop topics would be a way to reach faculty who did not think to come to the library for this help, and increase the impact of copyright services on institutional knowledge and culture. Looking at the information provided on library web sites as an indication of the type of information required of the academic librarian in charge of copyright information services, the incumbent of such a position would also be developing materials, websites, and providing instruction on fair use, author rights, the public domain, requesting permissions, and open access to meet patron and library demands for information. Based on the literature, the copyright information services librarian likely would also be asked to give input on policies related and adjacent to copyright services, be involved with the licensing of electronic 
resources, and give guidance to authors and open access journals provided and published by their library. They would be in contact with their legal counsel either informally or as an official liaison to that office. While the literature found that the colleagues of copyright librarians tended to shy away from providing any type of copyright information assistance themselves, the placement of the copyright service webpages and the, not infrequent, reference to groups providing copyright services seems to indicate that the copyright information services librarian does not necessarily work alone in the current academic library.

However, neither the literature nor the information gleaned from this study of library web pages addresses how copyright librarians integrate their services with those of their colleagues at their institutions. Libraries at Research 1 institutions vary greatly in organization and administration. While there seems to be some standardization in the types of services and information provided by libraries concerning copyright and intellectual property, there is also marked variation in how and by whom those services and information are supplied. Also not answered by the current study is whether, as a service that has been described in the literature as driven, in part, by user demand for information, copyright services at academic libraries are truly fulfilling user needs. Future study into the development of copyright librarian positions in academic libraries would be greatly enhanced by the collection of user feedback in a way that could be compared across several different types of organizations. 


\section{References}

Albitz, R. (2013). Copyright Information Management and the University Library: Staffing, Organizational Placement and Authority. Journal of Academic Librarianship, 39(5), 429435. https://doi.org/10.1016/i.acalib.2013.04.002

American Library Association. (2015, February 9). Framework for Information Literacy for Higher Education. American Library Association. Retrieved from http://www.ala.org/acrl/standards/ilframework

Bay, M. T. (2001). Copyright and the Need for Academic Libraries To Educate Patrons. https://eric.ed.gov/?id=ED455840

Brown, A. P. (2013). Library Publishing Toolkit. IDS Project Press. Retrieved from http://dscholarship.pitt.edu/19528/1/LPT Web.pdf

Carnegie Classification of Institutions of Higher Education. (2017). Basic Classification Description. Retrieved from http://carnegieclassifications.iu.edu/classification descriptions/basic.php

Carson, L. C., \& Greenhill, K. (2015). One hat or many? A comparison of two models for the Copyright Officer position in university libraries. Library \& Information Research. 39(121), 57. http://www.lirgjournal.org.uk/lir/ojs/index.php/lir/article/view/659

Charbonneau, D. H., \& Priehs, M. (2014). Copyright Awareness, Partnerships, and Training Issues in Academic Libraries. The Journal Of Academic Librarianship, 40228-233. https://doi.org/10.1016/i.acalib.2014.03.009

Cheng, S., \& Winter, C. (2014). Copyright skills in academic libraries. Feliciter, 60(2), 8. 
Running Head: COPYRIGHT EDUCATIONAL SERVICES

Cross, William M., and Phillip M. Edwards. (2011). Preservice Legal Education for Academic Librarians within ALA-Accredited Degree Programs. Portal: Libraries and the Academy $11(1): 533-50$.

Duncan, J., Clement, S., \& Rozum, B. (2013). Teaching Our Faculty: Developing Copyright and Scholarly Communication Outreach Programs. Retrieved from http://digitalcommons.usu.edu/lib pubs

Eye, J. (2013). Knowledge Level of Library Deans and Directors in Copyright Law. Journal of Librarianship \& Scholarly Communication, 2(1), 1-14. http://doi.org/10.7710/2162$\underline{3309.1103}$

Ferullo, D. L. (2004). Major Copyright Issues in Academic Libraries: Legal Implications of a Digital Environment. Journal of Library Administration, 40(1/2), 23-40. https://doi.org/10.1300/J111v40n01_03

Ferullo, D. (2011). Managing Copyright Services at a University. Reference and User Services Quarterly, 51(2), 111-

114. https://journals.ala.org/index.php/rusq/article/viewFile/4019/4555

Hansen, D. R., Cross, W. M., \& Edwards, P. M. (2013). Copyright Policy and Practice in Electronic Reserves among ARL Libraries. College \& Research Libraries, 74(1), 69-84. $\underline{\text { https://doi.org/10.5860/crl-313 }}$

Horava, T. (2008). Webpages on Copyright in Canadian Academic Libraries. Partnership: the Canadian Journal of Library and Information Practice and Research. 3(2). Retrieved from https://ruor.uottawa.ca/handle/10393/12865 
Running Head: COPYRIGHT EDUCATIONAL SERVICES

Kawooya, D., Veverka, A., \& Lipinski, T. (2015). The Copyright Librarian: A Study of Advertising Trends for the Period 2006-2013. The Journal of Academic Librarianship, 41(3), 341-349. https://doi.org/10.1016/j.acalib.2015.02.011

National Center for Education Statistics. (2017). Library Statistics Program: Compare Academic Libraries. Retrieved from https://nces.ed.gov/surveys/libraries/Compare/Default.aspx

Nilsson, I. (2016). Developing new copyright services in academic libraries. Insights: The UKSG Journal, 29(1), 78-83. https://doi.org/10.1629/uksg.276

Peet, L. (2014, August 13). Harvard launches CFRs: librarians are copyright first responders. Library Journal. Retrieved from https://li.libraryjournal.com/2014/08/copyright/harvards-copyright-first-responders-tothe-rescue/\#

Schmidt, L., English, M. (2015). Copyright Instruction in LIS Programs: Report of a Survey of Standards in the U.S.A. Journal of Academic Librarianship, 41(6): 736-743. http://dx.doi.org/10.1016/i.acalib.2015.08.004

Shachaf, P., \& Rubenstein, E. (2007). A Comparative Analysis of Libraries' Approaches to Copyright: Israel, Russia, and the U.S. The Journal of Academic Librarianship, 33(1), 94105. https://doi.org/10.1016/j.acalib.2006.06.005

Wang, Y., \& Yang, X. (2015). Libraries' positions on copyright: A comparative analysis between Japan and China. Journal of Librarianship \& Information Science, 47(3), 216. https://doi.org/10.1177/0961000614532484 